\title{
Size Distribution and Source Identification of Airborne Particulate Matter and Metallic Elements in a Typical Industrial City
}

\author{
Mai Tra Ny and Byeong-Kyu Lee* \\ Department of Civil and Environmental Engineering, University of Ulsan, Ulsan 680-749, Korea \\ *Corresponding author. Tel: +82-52-259-2864, E-mail: bklee@ulsan.ac.kr
}

\begin{abstract}
The size distribution of airborne particulate matter (PM) and the concentrations of associated metallic elements were investigated in a busy urban region of a typical Korean industrial city. The PM concentrations measured during the spring, except for those in the size range of 1.1 to $2.1 \mu \mathrm{m}$, were slightly higher than the PM concentrations in the summer. Coarse particles contributed greatly to the variation in PM concentrations in the spring, while fine and submicron particles contributed largely to the variation in PM concentrations in the summer. The difference in size modes of the PM concentrations between spring and summer may be explained by the Asian dust effect and its accompanying wind direction and speed. Extremely high enrichment factors (EFs) values $(6,971$ to 60,966$)$ for all of the size distributions in PM were identified for cadmium (Cd). High EFs values (12 to 907) were also identified for other heavy metals including $\mathrm{Cr}, \mathrm{Cu}, \mathrm{Ni}, \mathrm{Pb}, \mathrm{Zn}$ and $\mathrm{Mn}$. Low $\mathrm{EF}$ values $(0.29$ to 8.61$)$ were identified for $\mathrm{Ca}, \mathrm{K}, \mathrm{Mg}$ and $\mathrm{Na}$. These results support the common hypothesis that most heavy metals in ambient PM have anthropogenic sources and most light metals have crustal sources. The results of principal components analyses and cluster analyses for heavy metals indicate that the principal sources of PM and metals were emissions from non-ferrous metal smelters, oil combustion, incinerators, vehicular traffic and road dust.
\end{abstract}

Key words: Size distribution, Metallic elements, PCA, Cluster analysis, Correlation

\section{INTRODUCTION}

Elevated ambient concentrations of particulate matter (PM) and metals are considered a significant risk to human health especially in urban areas where many mobile and stationary sources emit large quantities of pollutants into the environment. Numerous studies have indicated an association between ambient PM concentrations and respiratory problems (Costa and Dreher, 1997; Hileman, 1981). Recent studies have shown that increased mortality and morbidity in the urban population is associated with increased PM and heavy metal concentrations in ambient air (Manoli et al., 2002; Dockery and Pope, 1994). Different sizes and compositions of particles can be associated with adverse effects on the environment and human health. Concentrations of chemicals contained in anthropogenic PM ranging from 0.001 to $2 \mu \mathrm{m}$ in diameter have been proven to be responsible for acid rain (Ning, 1995). The efficiency of inhalation and respiratory deposition of PM is dependent on particle size (Hinds, 1999). PM less than $10 \mu \mathrm{m}$ in diameter has the potential to reach the lower respiratory tract, while particles more than $5 \mu \mathrm{m}$ in diameter are usually filtered out by the upper respiratory tract. Fine particles with a diameter of less than $2 \mu \mathrm{m}$ find their way deep into the alveolar regions of the human lung, affecting lung function, particularly if the particles contain toxic metals (Infane and Acosta, 1991). Therefore, analyzing the size distribution and components of PM helps to identify its risks to human health and inform appropriate methods for controlling PM emissions.

Analyses of the components of PM in ambient air have usually been limited to evaluation of total suspended particles (TSP) classified as $\mathrm{PM}_{10}$ (less than or equal to $10 \mu \mathrm{m}$ ) or $\mathrm{PM}_{2.5}$ (less than or equal to $2.5 \mu \mathrm{m}$ ). Studies conducted during the last two decades have evaluated the association between the size distribution of PM and metal concentrations in urban areas. In the past, many researchers in Europe have conducted experiments to study the size distributions of PMbased metals (Voutsa and Samara, 2002; Allen et al., 2001; Fernandez Espinosa et al., 2001). In Asia, resear$\mathrm{ch}$ in this area is still evolving with a limited number of published studies on PM-based metal/elemental size distributions and concentrations (Srivastava et al., 2009; Srivastava and Jain, 2006; Wang et al., 2005; 
Parmar et al., 2001). However, these studies focused exclusively on the effects of PM size distribution on elemental concentrations.

A limited number of studies utilizing correlation analysis of size-based PM concentrations have been conducted. These included a study by Lundgren $e t$ al. (1996) that determined the relative concentrations of $\mathrm{PM}_{10} / \mathrm{PM}_{2.5} / \mathrm{PM}_{1}$ in the Phoenix, $\mathrm{AZ}$ area of the United States. Keywood et al. (1999) assessed the relationship between TSP, $\mathrm{PM}_{10}, \mathrm{PM}_{2.5}, \mathrm{PM}_{1}$ and ultra-fine particles $(<0.1 \mu \mathrm{m})$ at six urban sites in Australia and reported that $\mathrm{PM}_{1}$ comprised $50 \%$ of the $\mathrm{PM}_{10}$ on average. Recently, Lin and Lee (2004) documented the regression between $\mathrm{PM}_{10}$ and $\mathrm{PM}_{1}$. However, there is limited data available on the association between PM concentrations and the size distribution of other fractions in urban areas, where most of the world population lives.

The purpose of this study was to identify the relationships between the concentrations of the nine PM fractions in a typical industrial city in Korea and to determine the effects of seasonal and meteorological factors on $\mathrm{PM}_{10}$ concentrations. An additional purpose of this study was to identify the possible sources of elemental PM using principle components analysis and cluster analysis.

\section{METHODOLOGY}

\section{1 Study Area Descriptions}

The metropolitan city of Ulsan, located in the southeastern part of the country, is the largest industrial city in Korea with a population of more than 1.1 million. There are three national-scale industrial complexes (ICs) in Ulsan, including a petrochemical IC, a nonferrous metal IC and a mechanical and shipping IC, as well as four smaller local-scale ICs.

Airborne PM samples were collected from a residential area located within 100 to $120 \mathrm{~m}$ of an eight lane highway and a busy traffic rotary (Fig. 1). The average speed of the vehicles on the highway was $90 \mathrm{~km} / \mathrm{hr}$. The traffic rotary had an average traffic density of 5,000 vehicles/hr during the day. The rotary and the highway also had relatively high densities of diesel trucks and buses. There were many apartment complexes located within 100 to $200 \mathrm{~m}$ of the sampling site.

\section{2 Sample Collection}

The PM samples were obtained using an eight-stage cascade impactor (Tisch Environmental, Inc.) placed $12 \mathrm{~m}$ from the ground on the roof of a local official building and set with a constant flow rate of 28.1 L/min. Daily PM sampling was based on a $24 \mathrm{hr}$ mea- surement period and 16 daily samples were collected each month during the spring and summer (April to August, 2008). Glass fiber filters were used to collect particles in nine size intervals $(<0.4,0.4$ to $0.7,0.7$ to $1.1,1.1$ to $2.1,2.1$ to $3.3,3.3$ to $4.7,4.7$ to $5.8,5.8$ to 9.0 and 9.0 to $10.0 \mu \mathrm{m}$ ).

\subsection{Metal Analysis}

The filters were stored in an environmentally controlled chamber $\left(20^{\circ} \mathrm{C} \pm 2^{\circ} \mathrm{C}, 45 \pm 5 \% \mathrm{RH}\right)$ for $24 \mathrm{hrs}$ prior to weighing before and after sampling. The weights of the filters were accepted only after triplicate consecutive weights within $\pm 2 \mu \mathrm{g}$ were obtained. The gravimetry of the samples was determined using an analytical balance with a precision of $1 \mu \mathrm{g}$. In order to determine the concentrations of the metallic elements, a mixture of hydrochloric $(\mathrm{HCl})$ and nitric acid $\left(\mathrm{HNO}_{3}\right)$ was used to extract the metals from the filters. Each filter was cut into smaller pieces $(0.5 \mathrm{~mm} \times 2 \mathrm{~mm})$ and put into a vial with $30 \mathrm{~mL}$ of the mixture $(\mathrm{HCl}$ : $\left.\mathrm{HNO}_{3}=1: 1\right)$. Metallic elements were extracted using an ultrasonic bath at $90^{\circ} \mathrm{C}$ for $120 \mathrm{~min}$. The extracts were filtered into beakers using a micro filter with 45 $\mu \mathrm{m}$ pores and brought to a final volume of $50 \mathrm{~mL}$ using de-ionized water. The concentrations of 13 metals, including $\mathrm{Al}, \mathrm{Ca}, \mathrm{Na}, \mathrm{K}, \mathrm{Mg}, \mathrm{Mn}, \mathrm{Cd}, \mathrm{Ni}, \mathrm{Cr}$, $\mathrm{Pb}, \mathrm{Zn}, \mathrm{Cu}$ and $\mathrm{Fe}$, were analyzed using an Inductively Coupled Plasma-Atomic Emission Spectrophotometry (IPC-AES). The relative standard deviation (RSD) was less than $2 \%$ for the concentrations of all of the elements measured using the prepared standard solutions of the trace reference materials accredited by the US National Institute of Standards and Technology (NIST). Each solution was measured four times to obtain the concentrations of the elements. In addition, the detection limits of the metals were 1.67, 0.33, $0.58,1.52,1.14,0.26$ and $4.17(\mathrm{ng} / \mathrm{mL})$ for $\mathrm{Ni}, \mathrm{Cd}, \mathrm{Cr}$, $\mathrm{Cu}, \mathrm{Fe}, \mathrm{Mn}$ and $\mathrm{Pb}$, respectively, and 7.31, 0.03, 5.95, $1.64,1.32$ and $1.76(\mathrm{ng} / \mathrm{mL})$ for $\mathrm{Al}, \mathrm{Zn}, \mathrm{K}, \mathrm{Na}, \mathrm{Mg}$ and $\mathrm{Ca}$, respectively. The reproducibility of the analyzed metals were $1.247,0.797,1.524,0.941,0.840,0.990$ and $1.867(\%)$ for $\mathrm{Ni}, \mathrm{Cd}, \mathrm{Cr}, \mathrm{Cu}, \mathrm{Fe}, \mathrm{Mn}$ and $\mathrm{Pb}$, respectively, and $0.639,0.806,0.817,0.825,0.887$ and 0.697 (\%) for $\mathrm{Al}, \mathrm{Zn}, \mathrm{K}, \mathrm{Na}, \mathrm{Mg}$ and $\mathrm{Ca}$, respectively. Blank filters and dynamic blanks were exposed to the ambient air for approximately $10 \mathrm{sec}$ at the sampling site and then were handled, stored and treated identically to the collected PM filters. Triplicate blank tests were conducted using the same analysis method as that for the actual samples.

\section{4 Receptor Models}

The enrichment factors $(\mathrm{EF})$ of the metallic elements were utilized to identify the origin of the elements in 


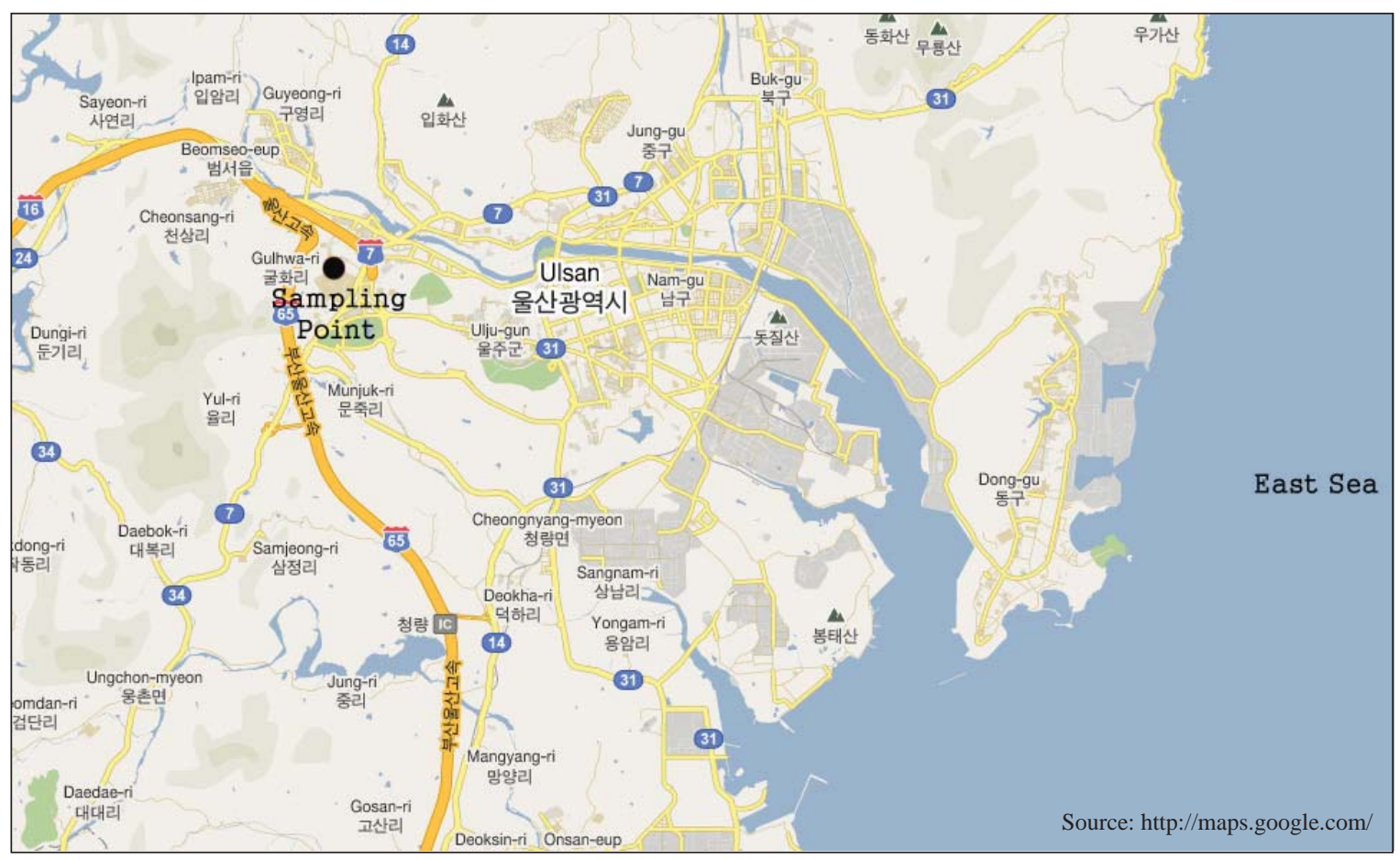

Fig. 1. A location map of the study area.

the atmosphere. Fe was selected as a reference element for the crust based on previous studies (Wang et al., 2006; Samara and Voutsa, 2005; Manoli et al., 2002). Natural sources contribute significantly to the composition of PM when the EF goes to unity and non-crustal sources are the predominant sources when the $\mathrm{EF}>10$ (Wang et al., 2006). The crustal average concentrations were obtained from Taylor's study (Taylor, 1996). The $\mathrm{EF}_{\text {crust }}$ of element $\mathrm{M}$ in PM was obtained using the following formula:

$$
E F_{\text {Crust }}=\frac{[M / F e]_{\text {Air }}}{[M / F e]_{\text {Crust }}},
$$

where $\mathrm{M}$ equals the concentration of the metal of concern, $[\mathrm{M} / \mathrm{Fe}]_{\text {Air }}$ is the concentration ratio of each metal depending on the size of each sample and [M/ $\mathrm{Fe}]_{\mathrm{Crust}}$ is the concentration ratio of each metal in the crust.

Principle components analysis (PCA) was used to obtain knowledge of emission inventories prior to this study (Chio et al., 2004). In the present study, the number of factors was selected so that the cumulative percentage variance explained by all of the chosen factors was greater than $56 \%$ and only those factors with an eigenvalue greater than 1 were chosen. A varimax rotation that maximized the variance of the squared elements was completed using SPSS software (ver- sion 13).

Cluster analysis (CA) was used to study the emitting sources of the different heavy metals found in the samples. Even though it is difficult to interpret dendrograms of unclear sample groups, we compared CA results with PCA results in order to be more confident in the final identification of sources. In this study, the groups were chosen based on dendrograms using Ward's method including the squared Euclidean distance and an agglomeration schedule.

\section{RESULTS AND DISCUSSION}

\section{1 Seasonal Size Distributions}

Fig. 2 reveals seasonal changes in the average PM concentrations of nine fractions. The highest PM levels during the spring (April and May) were observed in the largest PM (9 to $10 \mu \mathrm{m})$ followed by the finest size $(0.4$ to $0.7 \mu \mathrm{m})$, one fine particle fraction $(0.7$ to $1.1 \mu \mathrm{m})$ and one coarse fraction $(5.8$ to $9.0 \mu \mathrm{m})$. In the summer (June to August), the highest PM levels were also observed in the size range of 9 to $10 \mu \mathrm{m}$ followed by the fine particle fractions ( 0.7 to 1.1 and 1.1 to 2.1 $\mu \mathrm{m})$.

In a comparison of wind characteristics between the spring and summer sampling periods (Fig. 3), stronger 
winds (with a wind speed of greater than $4 \mathrm{~m} / \mathrm{s}$ ) and more fractions of southern and southwestern wind series occurred during the spring. Therefore, the PM collected during the spring sampling period was expected originate from a greater variety of sources than the PM collected in the summer when a southeastern series of winds prevailed. In addition, the presence of some western series of winds during the spring indicated that the PM collected during the spring would be affected by the Asian dust that usually originates from the west or northwest of the sampling site. In a comparison of PM size distribution between the spring and

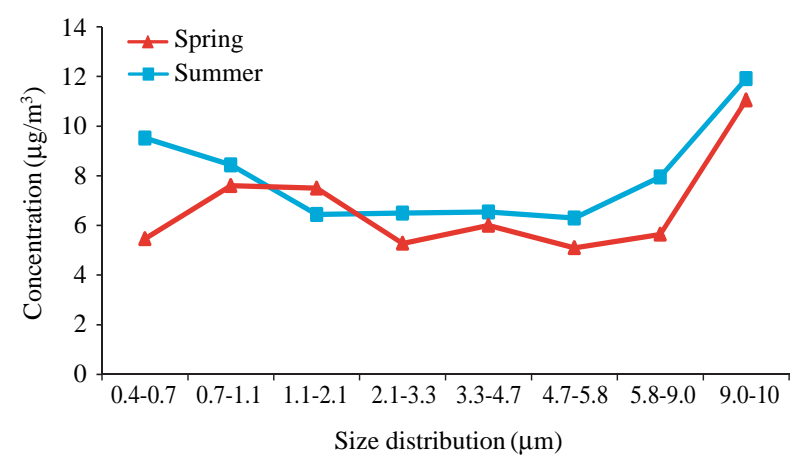

Fig. 2. PM concentrations for each size group during the spring and summer periods.

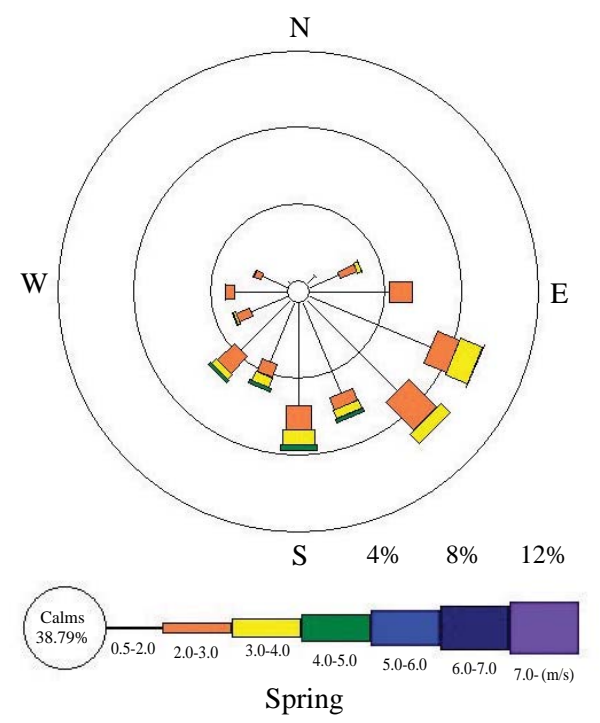

summer periods, the PM collected in the spring had increased concentrations of coarse particles due to the Asian dust. However, the PM collected in the summer would be affected more by the winds that pass through industrial areas.

\section{2 Correlations between $\mathrm{PM}_{10}$ and Other PM Sizes}

Table 1 presents the coefficients of determination $\left(r^{2}\right)$ between each PM size fraction and the $\mathrm{PM}_{10}$ concentrations during two seasons. In the spring, strong correlations existed between the $\mathrm{PM}_{10}$ and coarse particles. In particular, the $\mathrm{PM}_{10}$ concentrations and the coarse particles with concentrations in the range of 4.7 to $5.8 \mu \mathrm{m}$ showed the strongest correlation $\left(r^{2}=\right.$ $0.87)$. The weakest correlation $\left(r^{2}=0.18\right)$ was obtained between the submicron particles $(0.4$ to $0.7 \mu \mathrm{m})$ and $\mathrm{PM}_{10}$. These results suggest that coarse particles have a strong influence on the observed variability in $\mathrm{PM}_{10}$ concentrations during the spring. While high correlations were obtained between most fine particles, the coefficients of determination between $\mathrm{PM}_{10}$ concentrations and 0.7 to $1.1 \mu \mathrm{m}$ and 1.1 to $2.1 \mu \mathrm{m}$ particles in the summer were 0.76 and 0.73 , respectively. The weakest correlation of concentration was between $\mathrm{PM}_{10}$ and coarse particles in the range of 9 to $10 \mu \mathrm{m}$ $\left(r^{2}=0.30\right)$. These results revealed that fine particles

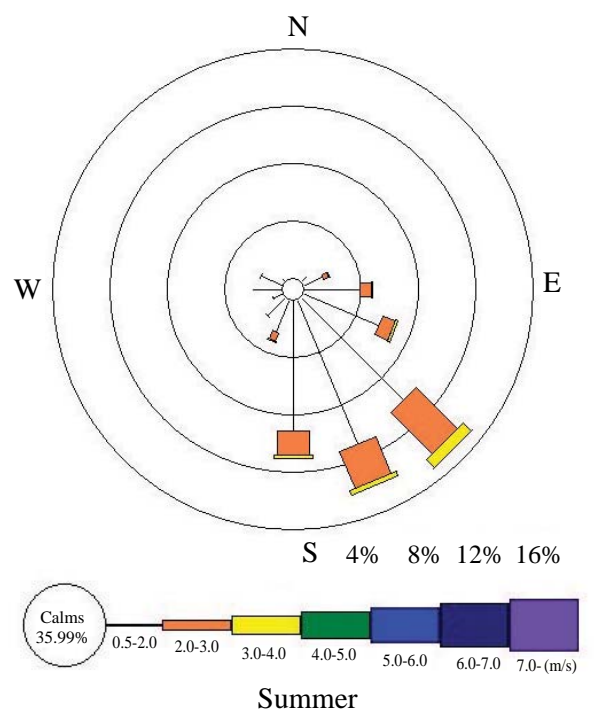

Fig. 3. Average wind rose at the sampling site during the spring and summer periods.

Table 1. Coefficients of determination $\left(r^{2}\right)$ between $\mathrm{PM}_{10}$ and different fractions.

\begin{tabular}{lccccccccc}
\hline Season & & $0.4-0.7 \mu \mathrm{m}$ & $0.7-1.1 \mu \mathrm{m}$ & $1.1-2.1 \mu \mathrm{m}$ & $2.1-3.3 \mu \mathrm{m}$ & $3.3-4.7 \mu \mathrm{m}$ & $4.7-5.8 \mu \mathrm{m}$ & $5.8-9.0 \mu \mathrm{m}$ & $9.0-10 \mu \mathrm{m}$ \\
\hline Spring & $\mathrm{PM}_{10}$ & 0.18 & 0.57 & 0.55 & 0.67 & 0.51 & 0.87 & 0.65 & 0.70 \\
Summer & $\mathrm{PM}_{10}$ & 0.60 & 0.76 & 0.73 & 0.57 & 0.56 & 0.44 & 0.48 & 0.30 \\
\hline
\end{tabular}




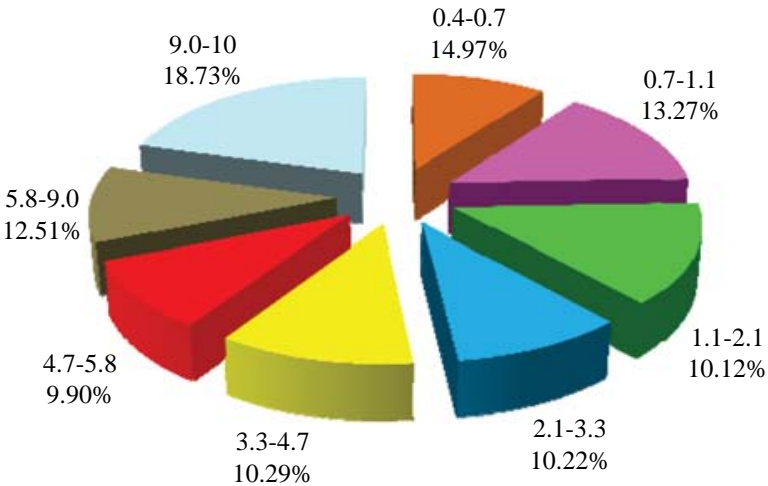

Spring

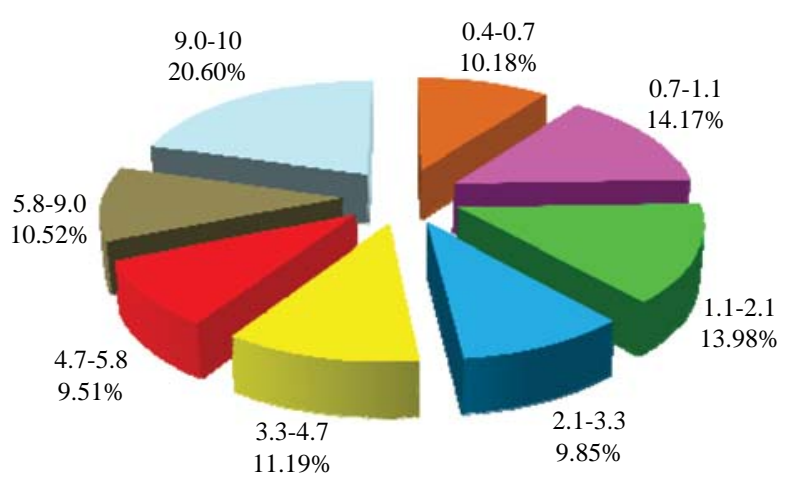

Summer

Fig. 4. Contribution of size-based $\mathrm{PM}$ components to $\mathrm{PM}_{10}$.

have a strong influence on the observed variability in $\mathrm{PM}_{10}$ concentrations in the summer season.

Recent studies have indicated that $\mathrm{PM}_{2.5}$ is the main component of $\mathrm{PM}_{10}$ from urban locations. Harrison et al. (1997) found that up to $60 \%$ of $\mathrm{PM}_{10}$ in Birmingham was composted of $\mathrm{PM}_{2.5}$. Clarke et al. (1999) reported that approximately 60 to $70 \%$ of urban $\mathrm{PM}_{10}$ was composed of $\mathrm{PM}_{2.5}$. Kim et al. (2000a) and (2000b) studied variations in the $\mathrm{PM}_{2.5}$ to $\mathrm{PM}_{10}$ ratio within the south coast air basin of southern California and found that $52 \%$ to $59 \%$ of the $\mathrm{PM}_{10}$ was composed of fine particles $\left(\mathrm{PM}_{2.5}\right)$. Fernandez Espinosa et al. (2001) studied the size distribution of ambient aerosols in Seville, Spain, and found that $\mathrm{PM}_{2.5}$ represented $72 \%$ of the $\mathrm{PM}_{10}$. In the current study, however, $41.4 \%$ and $41.2 \%$ of the $\mathrm{PM}_{10}$ concentrations consisted of $\mathrm{PM}_{2.5}$ in the spring and summer seasons, respectively (Fig. 4). The fractions of fine particles in this study were much lower than those in other studies. These results indicated that the fraction of coarse particles in the $\mathrm{PM}_{10}$ was much higher than the fractions recorded in other studies. The increase in coarse fractions indicated higher contributions of crustal elements, particles from mechanical sources and suspended particles from the movement of vehicles. The PM collected at the site could easily be affected by traffic related sources such as the abrasion of brake systems, tires and road surfaces, since the sampling site was located near the highway and a busy traffic rotary area.

\section{3 Source Identification for Size-based Particles}

The PM correlations among different size fractions were determined by regression analysis as shown in Table 2. During the spring sampling period, there were strong correlations $(r=0.60-0.90, P<0.01)$ between all of the coarse particles above $2.1 \mu \mathrm{m}$. However, all of the fine particles below $2.1 \mu \mathrm{m}$ and some of the coarse particles less than $3.3 \mu \mathrm{m}$ were also highly correlated $(r=0.57-0.87, P<0.01)$ during the summer sampling period. Previous studies ( $\mathrm{Li}$ and Lin, 2003; Vallisu et al., 2000) found that $\mathrm{PM}_{2.5}$ and $\mathrm{PM}_{1}$ were highly correlated and therefore could have similar sources. These results indicate that high correlation coefficients for various particle size groups can be related to the same sources. Therefore, these results indicate that there were common or similar PM sources among the coarse particles in the spring and among the fine particles in the summer. For both of the seasons, strong correlations were identified between the size group 5.8 to $9.0 \mu \mathrm{m}$ and both fine particles $(0.4$ to 0.7 and 0.7 to $1.1 \mu \mathrm{m}$ ) and the size groups 1.1 to $2.1,2.1$ to 3.3 and 3.3 to $4.7 \mu \mathrm{m}$. However, very weak correlations $(r=0.08-0.28, P<0.01)$ were noted in the summer between the size group of $9-10 \mu \mathrm{m}$ and the other particle size groups. These results indicated that the particles in the 9-10 $\mu \mathrm{m}$ size group have different sources than the other PM size groups. The 9-10 $\mu \mathrm{m}$ size group showed strong correlations with coarse particles in the spring. These results indicated that there was a common source of coarse particles, such as Asian dust, in the spring.

Table 3 shows the results of a factor analysis of the size fractionated $\mathrm{PM}$ in $\mathrm{PM}_{10}$. In spring, factor 1 explains $61.24 \%$ of the variance with high loading (0.72) of a fraction of fine particles (1.1-2.1 $\mu \mathrm{m})$ and also with high loading (0.82-0.96) of coarse particles (2.1 to $10 \mu \mathrm{m})$. Coarse particles have been used in the past as markers for road and soil dust (Houck et al., 1990). Therefore, this factor can be identified as road dust and soil dust. Factor 2 explains $18.79 \%$ of the variance with high loading of submicron particles in the size groups of 0.4 to $0.7 \mu \mathrm{m}(0.91)$ and 0.7 to 1.1 $\mu \mathrm{m}(0.85)$. Submicron particles are used as indicators 
Table 2. Correlation coefficients $(r)$ of different size fractions during two seasons.

\begin{tabular}{|c|c|c|c|c|c|c|c|c|c|}
\hline Season & PM size & $0.4-0.7 \mu \mathrm{m}$ & $0.7-1.1 \mu \mathrm{m}$ & $1.1-2.1 \mu \mathrm{m}$ & $2.1-3.3 \mu \mathrm{m}$ & $3.3-4.7 \mu \mathrm{m}$ & $4.7-5.8 \mu \mathrm{m}$ & $5.8-9 \mu \mathrm{m}$ & $9-10 \mu \mathrm{m}$ \\
\hline \multirow{8}{*}{ Spring } & $0.4-0.7 \mu \mathrm{m}$ & 1 & & & & & & & \\
\hline & $0.7-1.1 \mu \mathrm{m}$ & 0.63 & 1 & & & & & & \\
\hline & $1.1-2.1 \mu \mathrm{m}$ & 0.11 & 0.52 & 1 & & & & & \\
\hline & $2.1-3.3 \mu \mathrm{m}$ & 0.15 & 0.53 & 0.56 & 1 & & & & \\
\hline & $3.3-4.7 \mu \mathrm{m}$ & 0.05 & 0.21 & 0.41 & 0.6 & 1 & & & \\
\hline & $4.7-5.8 \mu \mathrm{m}$ & 0.16 & 0.58 & 0.74 & 0.9 & 0.77 & 1 & & \\
\hline & $5.8-9 \mu \mathrm{m}$ & -0.11 & 0.36 & 0.67 & 0.72 & 0.77 & 0.88 & 1 & \\
\hline & $9-10 \mu \mathrm{m}$ & 0.1 & 0.39 & 0.59 & 0.65 & 0.73 & 0.79 & 0.85 & 1 \\
\hline \multirow{8}{*}{ Summer } & $0.4-0.7 \mu \mathrm{m}$ & 1 & & & & & & & \\
\hline & $0.7-1.1 \mu \mathrm{m}$ & 0.81 & 1 & & & & & & \\
\hline & $1.1-2.1 \mu \mathrm{m}$ & 0.69 & 0.87 & 1 & & & & & \\
\hline & $2.1-3.3 \mu \mathrm{m}$ & 0.81 & 0.77 & 0.73 & 1 & & & & \\
\hline & $3.3-4.7 \mu \mathrm{m}$ & 0.57 & 0.65 & 0.7 & 0.64 & 1 & & & \\
\hline & $4.7-5.8 \mu \mathrm{m}$ & 0.5 & 0.43 & 0.51 & 0.42 & 0.72 & 1 & & \\
\hline & $5.8-9 \mu \mathrm{m}$ & 0.64 & 0.6 & 0.62 & 0.62 & 0.65 & 0.45 & 1 & \\
\hline & $9-10 \mu \mathrm{m}$ & 0.13 & 0.26 & 0.2 & 0.08 & 0.12 & 0.28 & 0.1 & 1 \\
\hline
\end{tabular}

Table 3. Factor analysis of size fractionated $\mathrm{PM}_{10}$.

\begin{tabular}{lrrrrr}
\hline \multirow{2}{*}{ Various sizes } & \multicolumn{2}{c}{ Spring } & & \multicolumn{2}{c}{ Summer } \\
\cline { 2 - 3 } \cline { 5 - 6 } & $\mathrm{F} 1$ & $\mathrm{~F} 2$ & & $\mathrm{~F} 1$ & $\mathrm{~F} 2$ \\
\hline $0.4-0.7 \mu \mathrm{m}$ & & 0.91 & & 0.88 & \\
$0.7-1.1 \mu \mathrm{m}$ & & 0.85 & & 0.88 & \\
$1.1-2.1 \mu \mathrm{m}$ & 0.72 & & & 0.87 & \\
$2.1-3.3 \mu \mathrm{m}$ & 0.82 & & & 0.89 & \\
$3.3-4.7 \mu \mathrm{m}$ & 0.83 & & 0.80 & \\
$4.7-5.8 \mu \mathrm{m}$ & 0.94 & & 0.57 & 0.51 \\
$5.8-9 \mu \mathrm{m}$ & 0.96 & & 0.79 & \\
$9-10 \mu \mathrm{m}$ & 0.88 & & & 0.94 \\
Eigen values & 4.90 & 1.50 & & 4.91 & 1.04 \\
\%Variance & 61.24 & 18.79 & 61.37 & 13.01 \\
\hline
\end{tabular}

Note, F stands for a factor.

of emissions from diesel truck exhaust and oil combustion (Houck et al., 1990). Therefore, this factor can be used to identify both diesel truck exhaust and oil combustion sources. Similarly, two factors were also found in the summer. Fuel combustion was responsible for high loading ( 0.79 to 0.88$)$ of the fine particles $(0.4$ to $2.1 \mu \mathrm{m})$ and most of the coarse particles $(2.1$ to $9 \mu \mathrm{m})$, with the exception of the 9 to $10 \mu \mathrm{m}$ size group (Kenneth et al., 1998). Factor 2 only explained $13.01 \%$ of the variance with high loading of 9.0 to $10 \mu \mathrm{m}(0.94)$ in the summer, indicating that the factor could be identified as road dust (Houck et al., 1990).

\section{4 Enrichment Factors of Metallic Elements}

Table 4 shows the EF of the light metals including each classified particle size. The EF values of the light metals ( $\mathrm{Al}, \mathrm{Ca}, \mathrm{K}, \mathrm{Mg}$ and $\mathrm{Na}$ ) in all of the size fractions were less than 10 . The lowest $\mathrm{EF}$ values were for $\mathrm{Al}(0.33$ to 0.78$)$ and $\mathrm{Ca}(0.66$ to 1.8$)$; these values were deficient compared to the minimal enrichment (Sutherland, 1999). K (1.14 to 3.14), $\mathrm{Mg}$ (0.55 to 2.48) and $\mathrm{Na}$ (3.16 to 8.61) had moderate EF values. EF values below 10 imply that crustal sources are predominant for those particles (Kao et al., 1995). Manoli et al. (2002) reported that emissions from natural crustal sources were found mostly in coarse particle sizes. Wang et al. (2006) and Berg et al. (1994) reported the enrichment of $\mathrm{Mg}$ indicated a contribution from sea salts.

Most of the heavy metals $(\mathrm{Cd}, \mathrm{Pb}, \mathrm{Zn}, \mathrm{Cu}, \mathrm{Cr}$ and $\mathrm{Ni}$ ) in all of the PM size fractions and $\mathrm{Mn}$ in the fine particle size fraction had very high EF values. Fig. 5 shows the change in the EF values of heavy metals as a function of particle size. The highest EF values for the heavy metals were observed within the fine particle size group of 0.4 to $0.7 \mu \mathrm{m}$, with the exceptions of $\mathrm{Pb}$ and $\mathrm{Cu}$. The highest EFs for $\mathrm{Pb}$ and $\mathrm{Cu}$ were in the size group of 2.1 to $3.3 \mu \mathrm{m}$. The EF values generally decreased with increasing particle size. Cd (EF: 6,97160,966) was the most enriched element in all of the particle size fractions, followed by $\mathrm{Pb}$ (EF: 233 to 1,151), $\mathrm{Cr}$ (EF: 69 to 908), $\mathrm{Cu}$ (EF: 145 to 362), Ni 
Table 4. Enrichment factor (EF) values of light metals.

\begin{tabular}{ccccccccc}
\hline Metals & $0.4-0.7 \mu \mathrm{m}$ & $0.7-1.1 \mu \mathrm{m}$ & $1.1-2.1 \mu \mathrm{m}$ & $2.1-3.3 \mu \mathrm{m}$ & $3.3-4.7 \mu \mathrm{m}$ & $4.7-5.8 \mu \mathrm{m}$ & $5.8-9 \mu \mathrm{m}$ & $9-10 \mu \mathrm{m}$ \\
\hline $\mathrm{Al}$ & 0.36 & 0.29 & 0.39 & 0.78 & 0.41 & 0.46 & 0.33 & 0.33 \\
$\mathrm{Ca}$ & 0.69 & 0.60 & 0.66 & 1.57 & 1.02 & 1.07 & 1.53 & 1.80 \\
$\mathrm{~K}$ & 1.43 & 1.17 & 1.52 & 3.14 & 1.67 & 1.81 & 1.14 & 1.15 \\
$\mathrm{Mg}$ & 1.17 & 0.96 & 1.23 & 2.48 & 1.32 & 1.44 & 0.55 & 0.57 \\
$\mathrm{Na}$ & 4.02 & 3.16 & 4.23 & 8.61 & 4.63 & 4.86 & 3.84 & 3.73 \\
\hline
\end{tabular}
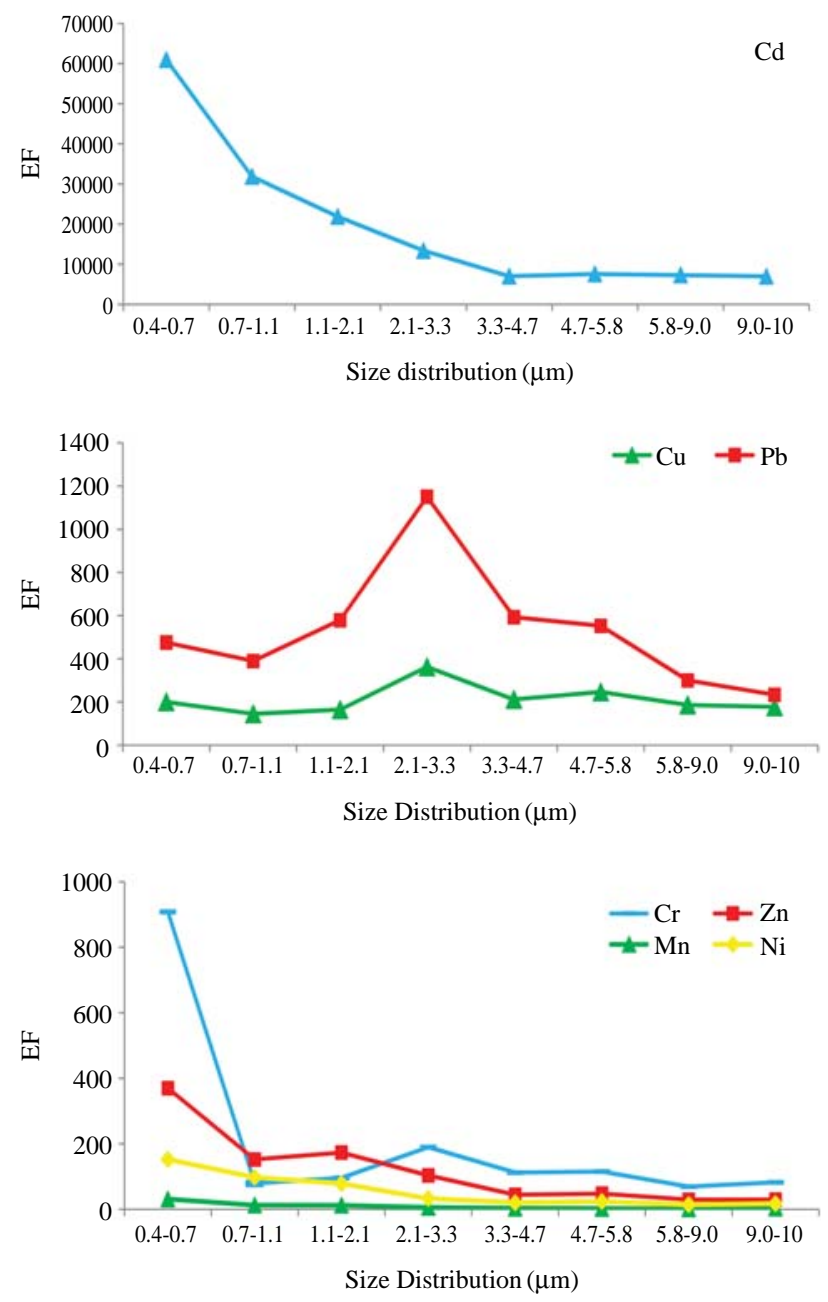

Fig. 5. Enrichment factors (EF) of heavy metals in PM as a function of the PM size.

(EF: 14 to 152 ) and Mn (EF: 12 to 31). In particular, the $\mathrm{EF}$ values of $\mathrm{Cd}$ in the fine particles that were smaller than $2.1 \mu \mathrm{m}$ ranged from 25,000 to 60,966 , which indicated a very high level of enrichment. Therefore, urgent countermeasures should be provided to reduce $\mathrm{Cd}$ levels in the atmosphere. For the heavy metals noted above, non-crustal sources such as vehicular exhaust, fossil fuel combustion and several industrial processes are considered major emission sources
(Sabbioni and Zappia, 1993). Gao et al. (2002) also reported high EF values ranging from 200 to 20,000 for $\mathrm{Cu}, \mathrm{Pb}, \mathrm{Zn}$ and $\mathrm{V}$ in PM from the New York-New Jersey harbor estuary.

\section{5 Source Identification of Heavy Metals}

As indicated by the results of the EF analysis above, the $\mathrm{EF}$ values of the heavy metals $\mathrm{Cd}, \mathrm{Cr}, \mathrm{Cu}, \mathrm{Ni}, \mathrm{Pb}$ and $\mathrm{Zn}$ in all of the size fractions and $\mathrm{Mn}$ in the size fraction of 0.4 to $2.1 \mu \mathrm{m}$ were much higher than 10 . The majority of these metals in the air came from the emissions of non-crustal sources such as anthropogenic sources. Therefore, we reanalyzed the anthropogenic origins using the principle component analysis and cluster analysis for these elements in the current study. A factor analysis method using the varimax rotated principal component was applied in order to identify the major sources of the heavy metals.

As shown in Table 5, three factors were identified in the $\mathrm{PM}_{3.3-10}$ (coarse particles). Factor 1 explains $56.37 \%$ of the variance with high loading of $\mathrm{Cd}(0.94)$ and $\mathrm{Cu}(0.95) . \mathrm{Cd}, \mathrm{Pb}$ and $\mathrm{As}$ have been used as maker compounds for non-ferrous metal smelters and automobile emissions (Eddie et al., 1999; Fung et al., 1995) and $\mathrm{Cu}$ has often been used as an indicator of air emissions from the smelting industry (Harrision et al., 1997). Therefore, this factor can be identified as a non-ferrous metal smelter source. Factor 2 explains $22.15 \%$ of the variance and contains high loading of $\mathrm{Mn}(0.95), \mathrm{Cr}$ $(0.67)$ and $\mathrm{Pb}(0.65)$ which can indicate dust from traffic sources (Almeida et al., 2006; Fang et al., 2006). Factor 3 showed high loading of $\mathrm{Ni}(0.82)$ and $\mathrm{Zn}$ (0.88). Ni and $\mathrm{V}$ are used as indicators of emissions from oil combustion (Kowalczyk et al., 1982; Zoller et al., 1974). Zn has been used as a marker for heavy metals from waste combustion in incinerators (Wiles, 1996). Therefore, this factor can be identified as both oil combustion and incineration.

Three factors were also found in the case of $\mathrm{PM}_{1.1-3.3}$ (fine and coarse particles) accounting for a total of $75.27 \%$ of the variance. Incineration and traffic dust were responsible for high loadings of $\mathrm{Cr}(0.88)$ and Zn (0.8) in factor 1 (Viana et al., 2008; Fang et al., 2006). Factor 2 in $\mathrm{PM}_{1.1-3.3}$ could represent a non-ferrous metal smelter source which has a high loading of 
Table 5. Factor loadings for the principal components analysis of metals in different PM fractions.

\begin{tabular}{|c|c|c|c|c|c|c|c|c|}
\hline & \multicolumn{2}{|c|}{$\mathrm{PM}_{0.4-1.1}$} & \multicolumn{2}{|c|}{$\mathrm{PM}_{1.1-3.3}$} & & & \multicolumn{2}{|l|}{$\mathrm{PM}_{3.3-10}$} \\
\hline & $\mathrm{F} 1$ & $\mathrm{~F} 2$ & $\mathrm{~F} 1$ & $\mathrm{~F} 2$ & F3 & $\mathrm{F} 1$ & $\mathrm{~F} 2$ & F3 \\
\hline $\mathrm{Cd}$ & 0.92 & -0.2 & 0.41 & 0.7 & 0.39 & 0.94 & -0.03 & 0.28 \\
\hline $\mathrm{Cr}$ & 0.62 & 0.71 & 0.88 & 0.03 & 0.14 & 0.32 & 0.67 & 0.52 \\
\hline $\mathrm{Cu}$ & 0.94 & -0.02 & 0.49 & 0.74 & 0.2 & 0.95 & 0.11 & 0.19 \\
\hline $\mathrm{Mn}$ & -0.19 & 0.86 & 0.46 & -0.75 & 0.19 & -0.19 & 0.95 & 0.05 \\
\hline $\mathrm{Ni}$ & 0.42 & -0.13 & 0.14 & 0.07 & 0.72 & 0.19 & -0.09 & 0.82 \\
\hline $\mathrm{Pb}$ & 0.31 & -0.74 & -0.01 & 0.06 & 0.9 & 0.51 & 0.65 & -0.04 \\
\hline $\mathrm{Zn}$ & 0.58 & 0.52 & 0.8 & 0.13 & 0.02 & 0.13 & 0.24 & 0.88 \\
\hline Eigen values & 2.76 & 2.1 & 2.76 & 1.35 & 1.57 & 3.24 & 1.55 & 1.3 \\
\hline$\%$ of Variance & 39.48 & 30.14 & 39.44 & 19.3 & 16.54 & 46.37 & 22.15 & 16.1 \\
\hline
\end{tabular}

Note, $F$ stands for a factor.

$\mathrm{Cd}(0.7), \mathrm{Cu}(0.74)$ and $\mathrm{Mn}(-0.75)$ accounting for $19.30 \%$ of the total variance (Harrision et al., 1997; Fung et al., 1995). Factor 3 only explained $16.54 \%$ of the total variance with high loading of $\mathrm{Pb}(0.9)$ and $\mathrm{Ni}(0.72)$, suggesting that this factor can be identified as oil combustion and vehicle emissions (Balacchandran et al., 2000; Pio et al., 1989).

For $\mathrm{PM}_{0.4-1.1}$ (fine particles), two factors were obtained with eigenvalues that were greater than 1 and explained $69.62 \%$ of the total variance. Factor 1 explained $39.47 \%$ of the variance with high loading of $\mathrm{Cd}$ (0.92) and $\mathrm{Cu}(0.94)$. Non-ferrous metals smelting, such as that of $\mathrm{Zn}$ or $\mathrm{Cu}$, was indicated as the source for this factor (Harrision et al., 1997; Fung et al., 1995). Factor 2 explained $30.14 \%$ of the total variance with a high loading of $\mathrm{Cr}(0.71), \mathrm{Mn}(0.86)$ and $\mathrm{Pb}(-0.74)$. The dust from traffic sources was responsible for factor 2 (Fang et al., 2006).

In this study, we tried to compare our cluster analysis results to our principal components analysis results in order to obtain more confident results for the source identification of heavy metals. Fig. 6 shows the dendrograms that resulted from using the Ward method for a cluster analysis of heavy metals. The results of the CA based on the dendograms basically agreed with the results of the PCA. However, there was a slight difference between the two methods for the identification of the source groups (Table 6). For example, factor 2 in the CA included $\mathrm{Cr}$, Ni and $\mathrm{Zn}\left(\mathrm{PM}_{3.3-10}\right)$ and factor 2 in the PCA only included $\mathrm{Ni}$ and Zn. In general, the PCA analysis reduced the number of variables while capturing as much as possible of the original information. Therefore, the variables in PCA, which have similar characteristics, could be arranged into the same factors (Fang et al., 2004). For the cluster analysis, the variables which have short distances in the dendograms could be basically classified into similar or the same source groups. Sometimes, it is difficult to interpret the CA results clearly. Even though
Dendrogram using ward method

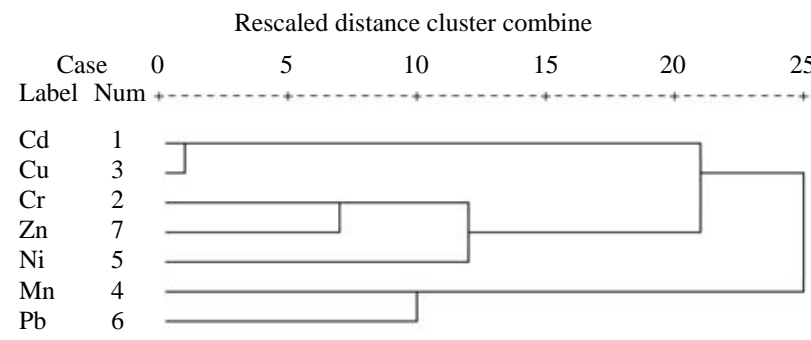

(a) $\mathrm{PM}_{3.3-10}$
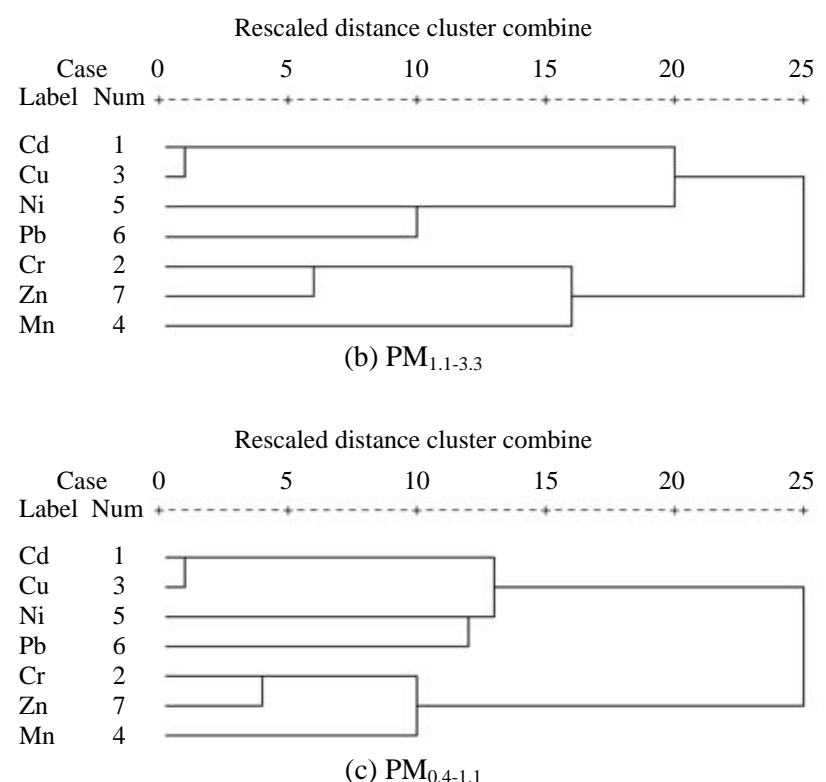

Fig. 6. Cluster analysis of heavy metals in different size PM.

the variables look like a similar or the same group based on the CA dendogram feature, they can be located in some distances which may not be considered as a similar source group. This case brings us unclear source identification. However, the CA classification 
Table 6. Comparison between the results of principal components analysis (PCA) and cluster analysis (CA).

\begin{tabular}{|c|c|c|c|c|c|}
\hline \multicolumn{2}{|c|}{$\mathrm{PM}_{0.4-1.1}$} & \multicolumn{2}{|c|}{$\mathrm{PM}_{1.1-3.3}$} & \multicolumn{2}{|c|}{$\mathrm{PM}_{3.3-10}$} \\
\hline PCA & $\mathrm{CA}$ & PCA & $\mathrm{CA}$ & PCA & $\mathrm{CA}$ \\
\hline $\mathrm{F} 1: \mathrm{Cd}, \mathrm{Cu}, \mathrm{Cr}$ & $\mathrm{G} 1: \mathrm{Cd}, \mathrm{Cu}, \mathrm{Ni}, \mathrm{Pb}$ & $\mathrm{F} 1: \mathrm{Cr}, \mathrm{Zn}$ & $\mathrm{G} 1: \mathrm{Cr}, \mathrm{Mn}, \mathrm{Zn}$ & $\mathrm{F} 1: \mathrm{Cd}, \mathrm{Cu}$ & $\mathrm{G} 1: \mathrm{Cd}, \mathrm{Cu}$ \\
\hline $\mathrm{F} 2: \mathrm{Cr}, \mathrm{Mn}, \mathrm{Pb}$ & $\mathrm{G} 2: \mathrm{Cr}, \mathrm{Zn}, \mathrm{Mn}$ & $\mathrm{F} 2: \mathrm{Cd}, \mathrm{Cu}, \mathrm{Mn}$ & $\mathrm{G} 2: \mathrm{Cd}, \mathrm{Cu}$ & $\mathrm{F} 2: \mathrm{Cr}, \mathrm{Mn}, \mathrm{Pb}$ & $\mathrm{G} 2: \mathrm{Mn}, \mathrm{Pb}$ \\
\hline & & $\mathrm{F} 3: \mathrm{Ni}, \mathrm{Pb}$ & $\mathrm{G} 3: \mathrm{Ni}, \mathrm{Pb}$ & F3: Ni, Zn & $\mathrm{G} 3: \mathrm{Cr}, \mathrm{Ni}, \mathrm{Zn}$ \\
\hline
\end{tabular}

Note, PCA and CA stand for principle component analysis and cluster analysis, respectively. F and G stand for a factor and a group, respectively.

can also provide simplicity when interpreting the relationship among the components using the distance information. Therefore, PCA and CA are both unique methods for the source identification of the materials of interest in terms of providing the possibility of various sources.

\section{CONCLUSIONS}

Through the analysis of the size and concentration distribution of the airborne particles and associated metals in a busy, urban, residential area of a typical industrial city in Korea, we reached the following conclusions.

The PM concentrations of various size fractions in $\mathrm{PM}_{10}$ were slightly higher in the spring than in summer. The $\mathrm{PM}_{10}$ concentrations showed strong correlations with coarse particles in the spring and with fine particles in summer. Particles of the 9 to $10 \mu \mathrm{m}$ size fraction did not show a strong correlation with the other sized particles in the summer.

Heavy metals were enriched in the PM we examined. In particular, $\mathrm{Cd}$ in $\mathrm{PM}$ was extremely enriched since it has an EF range of 6,971 to 60,966. The EF values of $\mathrm{Pb}, \mathrm{Cr}, \mathrm{Cu}$ and $\mathrm{Ni}$ were 233 to $1,151,69$ to 908 , 145 to 362 and 14 to 152 , respectively, indicating that they were the product of contamination by anthropogenic sources. The major sources of the heavy metals identified through principal components analysis and cluster analysis were air emissions from non-ferrous metal smelting, traffic, oil combustion and incineration.

\section{ACKNOWLEDGEMENTS}

This work was supported by the 2007 research funds of the University of Ulsan, Ulsan, Korea.

\section{REFERENCES}

Allen, A.G., Nemitz, E., Shi, J.P., Harrison, R.M., Greenwood, J.C. (2001) Size distributions of trace metals in atmospheric aerosols in the United Kingdom. Atmospheric Environment 35, 4581-4591.

Almeida, S.M., Pio, C.A., Freitas, M.C., Reis, M.A., Trancoso, M.A. (2006) Source apportionment of atmospheric urban aerosol based on weekdays/weekend variability: evaluation of road re-suspended dust contribution. Atmospheric Environment 40, 2058-2067.

Balachandran, S., Meean, B.R., Khillare, P.S. (2000) Particle size distribution and its elemental composition in the ambient air of Delhi. Environment International 26, 49-54.

Berg, T., Royset, O., Steinnes, E. (1994) Trace elements in atmospheric precipitation at Norwegian background stations (1989-1990) measured by ICP-MS, Atmospheric Environment 28, 3519-3536.

Chio, C.P., Cheng, M.T., Wang, C.F. (2004) Source apportionment to PM in different air quality conditions for Taichung urban and coastal areas, Taiwan. Atmospheric Environment 38, 6893-6905.

Clarke, A.G., Azadi-Boogar, G.A., Andrews, G.E. (1999) Particle size and chemical composition of urban aerosols. The Science of the Total Environment 235, 1524.

Costa, D.L., Dreher, K.L. (1997) Bioavailable transition metals in particulate matter mediate cardiopulmonary injury in healthy and compromised animal models. Environment and Health Perspectives 105, 1053-1060.

Dockery, D.W., Pope, C.A. (1994) Acute respiratory effects of particulate air pollution. Annual Reviews of Public Health 15, 107-132.

Eddie, L., Chan, C.K., Paatero, P. (1999) Application of positive matrix factorization in source apportionment of particulate pollutants in Hong Kong. Atmospheric Environment 33, 3201-3212.

Fang, G.C., Chang, C.N., Wu, Y.S., Fu, P.P.C., Yang, I.L., Chen, M.H. (2004) Characterization, identification of ambient air and road dust polycyclic aromatic hydrocarbons in central Taiwan, Taichung. Science of Total Environment 327, 135-146.

Fang, G.C., Wu, Y.S., Chang, S.Y., Huang, S.H., Rau, J.Y. (2006) Size distribution of ambient air particles and enrichment factor analyses of metallic elements at Taichung Harbor near the Taiwan Strait. Atmospheric Environment 81, 320-333.

Fernández Espinosa, A.J.F., Rodriguez, M.T., Rosa, F.J.B., Sanchez, J.C.J. (2001) Size distribution of metals in urban aerosols in Seville (Spain). Atmospheric 
Environment 35, 2595-2601.

Fung, Y.S., Wong, L.W.Y. (1995) Apportionment of air pollution sources by receptor models in Hong Kong. Atmospheric Environment 29, 2041-2048.

Gao, Y., Nelson, E.D., Field, M.P., Ding, Q., Li, H., Sherrell, R.M., Gigliotti, C.L., Van, D.A., Glenn, T.R., Eisenreich, S.J. (2002) Characterization of atmospheric trace elements on $\mathrm{PM}_{2.5}$ particlute matter over the New York- New Jersey harbor estuary. Atmospheric Environment 36, 1077-1086.

Harrison, R.M., Deacon, A.R., Jones, M.R. (1997) Sources and processes affecting concentrations of $\mathrm{PM}_{10}$ and $\mathrm{PM}_{2.5}$ particulate matter in Birmingham (UK). Atmospheric Environment 31, 4103-4117.

Hileman, B. (1981) Particulate matter: the inhalable variety. Environmental Science and Technology 15, 983986.

Hinds, W.C. (1999) Respiratory Deposition, in: Aerosol Technology. (2nd Ed.), Wiley, New York, pp. 233-259.

Houck, J.E., Goulet, J.M., Chow, J.C., Watson, J.G., Pritchett, L.C. (1990) Chemical characterization of emission sources contributing to light extinction. In Transactions, Visibility and Fine Particles, Air and Waste Management Association (Mathai, C.V. Ed), Pittsburgh, PA, pp. 437-446.

Infante, R., Acosta, I.L. (1991) Size distribution of trace metals in Ponce, Puerto Rico air particulate matter. Atmospheric Environment 25B, 121-131.

Kao, A.S., Friedlander, S.K. 1995. Frequency distributions of $\mathrm{PM}_{10}$ chemical components and their sources, Environmental Science and Technology 29, 19-28.

Kenneth, W., Cecil, F.W., Wayne, T.D. (1998) Air Pollution: Its Origin and Control, 3rd Edn. Addison Wesley Longman.

Keywood, M.D., Ayers, G.P., Gras, J.L., Gillett, R.W., Cohen, D.D. (1999) Relationships between size segregated mass concentration data and ultrafine particle number concentrations in urban areas. Atmospheric Environment 33, 2907-2913.

Kim, B.M., Teffera, S., Zeldin, M. (2000a) Characterization of $\mathrm{PM}_{2.5}$ and $\mathrm{PM}_{10}$ in the South Coast Air Basin of Southern California: Part 2-temperial variations. Journal of the Air and Waste Management Association 50, 2045-2059.

Kim, S., Shen, S., Sioutas, C., Zhu, Y., Hinds, W.C. (2000b) Size distribution and diurnal and seasonal trends of ultrafine particles in source and receptor sites of the Los Angeles Basin. Journal of the Air and Waste Management Association 52, 297-307.

Kowalczyk, G.S., Gordon, G.E., Rheingrover, S.W. (1982) Identification of atmospheric particulate sources in Washington, DC, using chemical element balances. Environmental Science and Technology 16, 79-90.

Li, C.S., Lin, C.H. (2003) Carbon profile of residential indoor $\mathrm{PM}_{1}$ and $\mathrm{PM}_{2.5}$ in the subtropical region. Atmospheric Environment 37, 881-888.

Lin, J.J., Lee, L.-C. (2004) Characterization of the concentration and distribution of urban submicron $\left(\mathrm{PM}_{1}\right)$ aerosol particles. Atmospheric Environment 38, 469475.

Lundgren, D., Hlaing, D.N., Rich, T.A., Marple, V.A. (1996) $\mathrm{PM}_{10} / \mathrm{PM}_{2.5} / \mathrm{PM}_{1}$ data from a trichotomous sampler. Aerosol Science and Technology 25, 353-357.

Manoli, E., Voutsa, D., Samara, C. (2002) Chemical characterization and source identification apportionment of fine and coarse air particles in Thessaloniki, Greece. Atmospheric Environment 36, 949-961.

Ning, D. (1995) Aerosol size distribution and elemental composition in urban areas of Northern China. Atmospheric Environment 30, 2355-2362.

Parmar, R.S., Satsangi, G.S., Kumari, M., Lakhani, A., Srivastava, S.S., Prakash, S. (2001) Study of size distribution of atmospheric aerosol at Agara. Atmospheric Environment 35, 693-702.

Pio, C.A., Nunes, T.V., Borrego, C.A., Martins, J. (1989) Assessment of air pollution sources in an industrial atmosphere of particulate using principle component/ multilinear regression analysis. Science of the Total Environment 80, 279-292.

Sabbioni, C., Zappia, G. (1993) Characterization of particles emitted by domestic heating units fuelled by distilled oil. Atmospheric Environment 27A, 1331-1338.

Samara, C., Voutsa, D. (2005) Size distribution of airborne particulate matter and associated heavy metals in the roadside environment. Chemosphere 59, 11971206.

Srivastava, A., Jain, V.K. (2006) Size distribution and source identification of total suspended particulate matter and associated heavy metals in the urban atmosphere of Delhi. Chemosphere 68, 579-589.

Srivastava, A., Gupta, S., Jain, V.K. (2009). Winter-time size distribution and source apportionment of total suspended particulate matter and associated metals in Delhi. Science Research 92, 88-99.

Sutherland, R.A. (1999) Beb sediment-associated trace metals in an urban stream, Oahu, Hawaii. Environmental Geology 39, 611-627.

Taylor, S.R. (1996) Abundance of chemical elements in the continental crust: a new table. Geochimica et Cosmochimica Acta 28, 1273-1285.

Vallius, M.J., Ruuskanen, J., Mirme, A., Pekkanen, J. (2000) Concentrations and estimated soot content of $\mathrm{PM}_{1}, \mathrm{PM}_{2.5}$, and $\mathrm{PM}_{10}$ in a subarctic urban atmosphere. Environmental Science and Technology 34, 1919-1925.

Viana, M., Kuhlbusch, T.A.J., Querol, X., Alastuey, A., Harrison, R.M., Hopke, P.K., Winiwarter, W., Vallius, M., Szidat, S., Prévôt, A.S.H., Hueglin, C., Bloemen, H., Wåhlin, P., Vecchi, R., Miranda, A.I., Kasper-Giebl, A., Maenhaut, W., Hitzenberger, R. (2008) Source apportionment of particulate matter in Europe: A review of methods and results. Journal of Aerosol Science 39, 827-849.

Voutsa, D., Samara, C. (2002) Labile and bioaccessible fractions of heavy metals in the airborne particulate matter from urban and industrial areas, Atmospheric Environment 36, 3583-3590 
Wang, X., Sato, T., Xing, B., Tamamura, S., Tao, S. (2005) Source identification, size distribution and indicator screening of airborne trace metals in Kanazawa, Japan. Journal of Aerosol Science 36, 197-210.

Wang, X., Sato, T., Xing, B. (2006) Size distribution and anthropogenic sources apportionment of airborne trace metals in Kanazawa, Japan. Chemosphere 65, 24402448.
Wiles, C.C. (1996) Municipal solid waste combustion ash: State of the knowledge. Journal of Hazardous Materials 47, 325-344.

Zoller W.H., Gladney, E.S., Duce, R.A. (1974) Atmospheric concentration and sources of trace metals in the South Pole. Science 183, 198-200.

(Received 16 October 2009, accepted 2 December 2009) 